\title{
An Analysis of Symbolism in The Scarlet Letter
}

\author{
Dan Zheng \\ School of Foreign Languages \\ Chongqing Three Gorges University \\ Chongqing, China
}

\begin{abstract}
Nathaniel Hawthorne's unique gift was for the creation of strongly symbolic stories which touch the deepest roots of man's moral nature. The finest example is the recreation of The Scarlet Letter. It is a typical one of his ideal and artistic style and is regarded as the first American symbolic fiction, dealing with alienation, sin, punishment, and guilt. The scarlet letter "A", which covers through the whole novel, was given a variety of symbolic meanings. He expressed his feelings, emotions, will, and concept through the scarlet letter "A", natural scenery, and four major characters. This paper researches the symbolism in the novel from the following aspects: the changing symbolic meaning of the scarlet letter "A", the forest, scaffold, the names of the major characters described in the novel.
\end{abstract}

Keywords-The Scarlet Letter; symbolism; sin

\section{INTRODUCTION}

Nathaniel Hawthorne is a great romantic novelist in America in the 19th century and is considered to be the first greatest American fiction writer in the moralistic tradition. Hawthorne is outstanding in literature skill, especially in handling symbolism. His work-The Scarlet Letter is notable for its symbolism and was regarded as the first symbolic novel in American literature.

The story begins in the seventeenth century in Boston, which is under Puritan command. The husband-an old and ugly scholar remarry a young woman named Hester Prynne. However, he goes out for many years and doesn't come back. While waiting for her husband, Hester and a young local minister called Arthur Dimmesdale fall in love with each other. They commit adultery secretly. Because of Hester's Pregnancy, the secret was finally discovered. It is sinful that Hester and Dimmesdale love each other in that way because their love was forbidden in that strict society. It is sinful. Due to this fact, Hester is punished by society with a letter "A" on her chest, which is considered to be evil, a shame. The Scarlet Letter is a cultural allegory, in which the author indirectly tells the future of Puritanism. The Scarlet Letter is a sample in which America Romanticism adapted itself to American Puritanism.

Symbolism was widely used in every incident, detail, and character in the story. According to the traditional rhetoric of symbolism, two things were made into symbols. They must be very similar or quite the opposite of each other. However,

This article is sponsored by China Scholarship Council and Chongqing Humanities and Social Sciences projects (No.15SKG150) symbolism in The Scarlet Letter sometimes even breaks that tradition and makes completely subjective things into symbol. For example, the scarlet letter " $A$ " that Hester wears is linked with a meteor, of which the shape is like an " $A$ " in the sky, making the novel more profound and let us deeply think about the novel.

\section{ThE SyMbOLIC MEANINGS OF IN THE SCARLET LETTER AND SOME OBJECTS IN THE NOVEL}

\section{A. Adultery}

In this novel, the scarlet letter " $A$ " changes its meanings for many times. This change is very significant. It shows growth in the characters, and the community in which they live. At the very beginning, the letter " $A$ " was regarded as a kind of sin or evil. Then with the development of the story, it becomes a symbol of alone and alienation of the female character Hester. Finally, it becomes a symbol of able, admirable and angel.

The letter "A", worn on Hester's bosom, is a symbol of her adultery against Roger Chillingworth. Putting the letter " $A$ " on her chest and letting her show to the public is the puritan way of treating her as a criminal, for the crime of adultery. Hester is looked down upon as if she is some sort of demon from hell that commits a terrible crime. It is the common way to explain the symbolic meaning of the letter. The color of scarlet is the symbol of blood and desire. Hester and Dimmesdale cannot control their love for each other and become the criminals of God. A woman losing her purity and a holy minister are punished for bringing shame to his religious occupation. Red should be regarded as the symbol of love and life, but under the control of the Puritan strictness, Hester has to wear the scarlet letter "A" was regarded as a symbol of shame and punishment.

Hester is ashamed of her sin, but she chooses to face reality rather than escape from it. In general, people may choose the way of leaving to some other places where nobody knows her sin. However, Hester is brave enough to continue to live her life, which shows her great strength and integrity.

\section{B. Alone and Alienation}

The scarlet letter "A" also symbolizes Hester's lonely life in New England. Hester's social life was virtually eliminated as a result of her shameful past. She has to live in such a community regardless of others' ironical words and with 
great courage and ability. The settle had been built by an earlier settler, and abandoned because the soil was too sterile to cultivation. Hester comes to have a part to perform in the world with her natural energy of character and rare capacity. However, there was nothing that made her feel as if she belonged to it. Every gesture, every word, and even the silence of those with whom she came to contact, implied, and often expressed, that she was banished, and as much alone as if she inhabited another sphere, or communicated with the common nature by other organs and senses than the rest of human kind. She stood apart from moral interests seemed to be the sole portion that she retained in the universal heart. Hester has no friends in the world, and little Pearl is the only companion of her lonely life. In other people's eyes, Hester is a criminal and be regarded as a shameful thing when someone wants to communicate with her.

\section{Able, Admirable and Angel}

The letter "A" was the symbol of her name, which is so powerful that many people refuse to interpret the scarlet letter 'A' by its original signification." We can see that the meaning of the scarlet letter "A" changes from adultery to being able, angel and admirable. In the beginning, people living in the town looked down upon the woman because of her crime. But later, they find that Hester is so skillfully in needlework, and she always helps the poor and sick without expecting any return or thanks. She is unselfish and always ready to help others considerately and patiently. People in the town then realize her noble nature and change the view on her. "Do you see that woman with the embroidered badge? It is our Hester - the town's own Hester - who is so kind to the poor, so helpful to the sick, so comforting to the afflicted!" The people in the town soon begin to regard the letter " $A$ " as a badge served to ward off the evil. It is a kind woman who should not shoulder the shame and be looked down upon by others. Hester is an angel sent by God to the people in the town. And she should win respect and sympathy of others instead of being punished by having to show her crime to the public by wearing the scarlet letter.

The three changes in the scarlet letter are significant. They show the progressive presentation of her sin, her lonely life, and her ability. Hester is an admirable woman who experiences more emotional torture than most people go through in a lifetime.

\section{The Symbolic MeAnings of the OBJects IN THE NOVEL}

\section{A. The Forest}

In The Scarlet Letter, the forest symbolizes much more than one could imagine. Each character brings out a different side of the forest. However, the forest also brings out a different side in each character. It is dark and secret. It is where people come to let loose and be themselves. The forest track leads away from the settlement out into the wilderness where all signs of civilization vanish. The forest track is precisely the escape route from the dictates of law and religion to The Promised Land to the west where men can breathe free air. For some people, the forest may be a place of evil thoughts and wrong things, but for others, it is a place of happiness and freedom. The open air of the forest is exhilarating but cold. Nothing is known in the wilderness, everything is up for grabs. There is no one around to stop you from going to the devil.

In addition, the forest is an open door to love and freedom for both Hester and Dimmesdale. It is a place where the letter on their bodies can no longer have an effect on them. It is a place where natural law is opposed to the strict artificial community with its human-made Puritan laws. The forest represents a thing of truth, whether it is good or bad. However, in Pearl's eyes, the forest has an entirely different concept, which is like a best friend. She is able to run and play freely to her innocent heart's content. The light is chasing her no matter where she goes. She can do that because her heart is innocent and the forest understands her. In the forest, young girl, middle-aged man and woman may throw away all the reluctance and finally be themselves under security and pull out secret thoughts. The forest brings out the natural semblance and natural personality of individuals who use it correctly.

\section{B. The Scaffold}

The scaffold symbolizes many aspects of human nature throughout the book. It expresses the shame and guilt of sin along with love and punishment. For example, when Hester commits adultery with Dimmesdale, the sin is committed out of love. After the secret was discovered, she was portrayed out of the society. When she stands on the scaffold, she hides her scarlet letter because the letter was viewed as a symbol of sin, shame, guilt, and punishment.

Besides serving as a form of public punishment and humiliation, the scaffold in The Scarlet Letter also helps to reveal the development of the story and characters involved with the sin of adultery. In The Scarlet Letter, there are three scaffold scenes representing sin. When Hester Prynne was accused of being an adulteress, this is the first scaffold scene.

The scaffold scene represents sinning. When Dimmesdale sits upon the scaffold during the night, this is the second scaffold which represents public sin. The thoughts are so overbearing that he screams a lot. The third and final scaffold scene is when Dimmesdale stands on the scaffold and he calls for Hester and Pearl. He then reveals his sin and dies. The final scaffold scene represents revealing sin and repenting sin. The scaffold scenes are the primary structures of the book and reflect the theme of sin and guilt. It could be viewed as a dark and evil place, but in the eyes of others, the scaffold could be a trusted safe shelter.

\section{The SYMBOLIC MEANING OF THE Four MAIN CHARACTERS}

\section{A. Hester Prynne}

Hester Prynne is one of the most important characters in The Scarlet Letter. Hester is the symbol of love, beauty, kindness and truth. She was described by Hawthorne like this: "The young woman was tall, a figure of perfect 
elegance on a large scale, she had dark and abundant hair, so glossy that it threw off the sunshine with a gleam, and a face which, besides being beautiful from regularity of feature and richness of complexion, had the impressiveness belonging to a marked brow and deep black eyes..." It is true that Hester is beautiful and attractive in appearance. But the most precious part of the character lies not only in her kindness toward other people, but also in her great courage of facing her love. Her love for the minister Dimmesdale is pure and true. It is the reason that she refuses to speak out the name of her partner in sin, but takes over all the punishment by herself. Instead of running from the hostile colonists, Hester withstands people's insolence and pursues a normal life. She proves her worth with her exceptional sewing skills and provides community service. Hester's sin gives her "sympathetic knowledge of the sin in other hearts." Even though the people she tries to help "often reviled the hand that was stretched forth to succor them." She continues to do unpaid work.

\section{B. Arthur Dimmesdale}

Arthur Dimmesdale is a young minister, whose initials are $\mathrm{AD}$, which also stands for adultery. Obviously, he should take part in the punishment for Hester. He loves Hester deeply and he is the father of Pearl, but he is not brave enough to admit their relationship. Only in the forest or in darkness, he can show his passion and love for Hester. So the word Dimmesdale also has symbolic meanings. Dim means dark and weak and dale means valley, so the name here is actually a symbol of the "dim-interior" of the clergyman. The scarlet letter " $A$ " in his heart symbolizes condemn in his deep heart. Meanwhile, it is also the symbol of the mental control of the Puritanism. "If thou feel it to be for thy soul's peace, and that the earthly punishment will thereby be made more effectual to salvation, I charge thee to speak out the name of the fellow-sinner and fellow-sufferer". He feels that he will have never been seen the same as before in front of God and that no amount of penitence can ever return him to God's good graces. He hates his hypocrisy to sin but dares not to tell the truth that he is the fellow-sinner of Hester. When he finally decides to expose the truth and tell his followers of how he deceives them, his fixation on his sin has utterly corroded him to the point of death. The only good that comes out of conceding his guilt is that he passes away without any secrets.

\section{Roger Chillingworth}

Another main character Roger Chillingworth is a man of complicated nature and abnormal psychology. The words "chilling" and "worth" compose the surname Chillingworth. Chilling comes from the word "chilling" which means this man is a merciless avenger. $\mathrm{He}$ is calm and kind in appearance but keeps evil intentions. All his strength and energy has been used to avenge. When the evil old man no longer has such a purpose, the devil takes him back to the hell. $\mathrm{He}$ is an unforgivable criminal. According to the explanation of the Christian and the Romantic period, the unforgivable crime means to infringe on others' soul and feelings to know about their reaction toward something. Chillingworth intends to look into the young minister's heart depending on some knowledge of medical science and miracle ways in religion. He pretends to be the young minister' true friend and moves close to him to torture and devastate Dimmesdale's heart. His curiosity and intention of avenge make him become the symbol of monster and evil. Due to his abnormal psychology, he also becomes a victim in the story. This character symbolizes the significant influence of the sin on people. Chillingworth also symbolizes that the Avenger's life is worthless. When he finds his wife betrays him, he devotes all his time and energy to seeking revenge. He forgets that he needs to lead a new life of his own. Therefore, he is the victim of his abnormal action.

\section{Pearl}

Pearl is one of the most complexes and misunderstood symbols in the novel. This character, throughout the story, develops into a dynamic symbol, which is always changing. Pearl is a source of many different kinds of symbolism. Firstly, she is the symbol of her mother's sin or the symbol of the scarlet letter. Secondly, Pearl is also a symbol of valuable thing with a high price. And we can understand that Pearl is the beautiful and precious crystallization of her parents' true love. For the mother Hester, Pearl is love rather than the burden.

\section{CONCLUSION}

As a great romantic novelist in America in the 19th century, Hawthorne was outstanding in handling the application of symbolism. The Scarlet Letter is Hawthorne's most important symbolic novel, which stands as the best work of Hawthorne and is one of the indubitable masterpieces of American literature. This thesis aims at the exploration of the usage of the symbolism in the novel. It mainly discusses the profound symbolic significance of the scarlet letter "A" and the four main characters. The scarlet letter " $A$ " is the central symbol of the novel. Its symbolic meaning changes from "adultery" to "able", even "angelic" in the novel. It also examines some typical natural surroundings such as the forest the scaffold that represent secret, freedom, sin, and so on.

The symbolic reading of The Scarlet Letter helps the readers understand more about the characters and the society they live. Through the analysis of the symbolic significance of the scarlet letter A and the natural environment that the characters situated, we can have a thorough understanding of the symbolism in the novel, and the novel The Scarlet Letter breaks literary standards of its time. Therefore, Hawthorne fully deserves the title "the prophet of symbolism." And The Scarlet Letter comes to be a work of the world.

\section{ACKNOWLEDGMENT}

I want to say thank you for the library of the University of Sheffield which provide me so many primary sources. I've used all of my passion to make this research better. And special thanks will be given by my colleagues. They give me useful guidance and valuable advice. 


\section{REFERENCES}

[1] Mao, Lingying. "Self and other:on the mirror images in The Scarlet letter", Foreign Literature Studies, June 2011, Vol.33(3). pp.81-88.

[2] Manheim, Daniel, “ Pearl's Golden Chain in The Scarlet Letter”, Peer Reviewed Journal, 2010 July-Sept, Vol.68(3), pp.177-180.

[3] Pirnajmuddin, Hossein, "The Carnivalesque in Nathaniel Hawthorne's The Scarlet Letter", Omid Teaching American Literature: A Journal of

[4] Theory and Practice, 2013 Spring, Vol.6(1), pp.106-119.

[5] Nathaniel Hawthorne, "The scarlet letter". Boston: Houghton Mifflin, 1960 .

[6] Sacvan Bercovitch, " The office of The scarlet letter", London: Johns Hopkins Univeristy Press.1991.

[7] Chase, Richard. "The American Novel and Its Tradition". New York: The Johns Hopkins University Press. 1957. 